\title{
HUMAN CAPITAL AS A TOOL FOR PREDICTING DEVELOPMENT OF TRANSPORT AND COMMUNICATIONS SECTOR: THE CZECH REPUBLIC PERSPECTIVE
}

Human capital as a part of intellectual capital has crucial impact on the overall development of all sectors of national economy. This trend can also be confirmed by the growing number of academic papers dealing with the issue. This paper presents results of a questionnaire survey that investigated the human capital in terms of selected motivational factors and employability prospects as seen by students of high schools programs related to transport and communications. The main objective was to get an insight into the current situation in the sector and its attractiveness as seen by potential future employees. The questionnaire survey was carried out in April 2016 and its respondents were future high school graduates, who can either continue to study transport and communications at university or enter the job market and search for a job in the sector straight away. Results obtained from a series of statistical tests using the Two-way ANOVA method can serve both companies and educational institutions as a basis for implementation of measures that would guarantee sustainable development of human resources in this field.

Keywords: human capital, transport, communications, employability, motivation, gender

\section{Introduction}

Human capital has gained increasing importance over the last few years. This fact is reflected in the growing number of research studies that recognize human capital as one of the key areas that are essential for the development of countries and companies as market players. Human capital is therefore one of the key social constructs which must be analyzed thoroughly in order to ensure effective management of all the processes that lead to increase in a company's value [1-4]. It can be examined in relation to a number of other measurable indicators and once a relationship is found among selected indicators, it is possible to predict future development in this area $[5,6]$.

Education is one of the main processes, which have fundamental impact on human capital. It is therefore vital to analyze education from the point of view of its participants, i.e. the people who help to create the future of human capital in a given sector of economy. By means of a targeted and longterm research it is possible to search for closer connections between current trends in the process of education and the process of social integration. Similarly to other sections of national economy, education is crucial for further development of transport and communications sector. It is thus necessary to create such conditions that would attract and motivate individuals to work in this sector. Because education shapes its participants, it is useful to analyze the whole process of education, especially from the point of view of the future graduates.

This article presents results of a questionnaire survey that was conducted among students of high schools, which offer study programs related to transport and communications and are associated in IT, Telecommunications, Postal Services and Logistics High Schools Association (henceforth, the Association). The ultimate objective is to identify trends of human capital in the sector of transport and communications. The analysis starts with the identification of the two main factors:

a) student's first - intention ("look for a job" or "continue to study"),

b) student's gender (male student or female student).

Students respond to questions related to two main areas:

a) perceived employability,

b) selected motivational factors.

\footnotetext{
* 'Dalibor Gottwald, ${ }^{1}$ Libor Svadlenka, ${ }^{1}$ Pavla Lejskova, ${ }^{2}$ Hana Pavlisova

${ }^{1}$ Department of Transport Management, Marketing and Logistics, Faculty of Transport Engineering, University of Pardubice, Czech Republic

${ }^{2}$ Department of English Language and Literature, Faculty of Education, Masaryk University Olomouc, Czech Republic

E-mail: libor.svadlenka@upce.cz
} 
Table 1 B2C Survey timetable

\begin{tabular}{|c|c|}
\hline \multirow[t]{2}{*}{ Date } & Activity \\
\hline & Research design \\
\hline \multirow[t]{7}{*}{ January - February 2016} & $\begin{array}{l}\text { Inform the headmistress of the } \\
\text { Association about the intented survey }\end{array}$ \\
\hline & Formulated hypotheses \\
\hline & Outline preliminary timetable \\
\hline & Define desired results \\
\hline & $\begin{array}{l}\text { Determine resources (human, } \\
\text { financial, non - financial) }\end{array}$ \\
\hline & $\begin{array}{l}\text { Consult high school representativnes } \\
\text { for respondents' relevance }\end{array}$ \\
\hline & Data collection methodology \\
\hline \multirow[t]{2}{*}{ February } & $\begin{array}{l}\text { Complete questionnaire and test its } \\
\text { pilot version }\end{array}$ \\
\hline & Design the electronic questionnaire \\
\hline \multirow[t]{2}{*}{ March 2016} & $\begin{array}{l}\text { Pilot testing of the electronic } \\
\text { questionnaire }\end{array}$ \\
\hline & $\begin{array}{l}\text { Send the link to the questionnaire to } \\
\text { school representatives }\end{array}$ \\
\hline \multirow[t]{2}{*}{ Apr 4 - Apr 22, 2016} & Collect data \\
\hline & Data processing \\
\hline \multirow[t]{3}{*}{ May 2016} & Data entry \\
\hline & $\begin{array}{l}\text { Select the final sample for statistical } \\
\text { testing }\end{array}$ \\
\hline & Analyze data \\
\hline June - September 2016 & Evaluate data \\
\hline September - December 2016 & Confront results with other works \\
\hline
\end{tabular}

This research is rather unique as there are currently no studies that would investigate the relationship between human capital and perceived employability and/or motivation to enter this particular sector.

\section{Background and methods}

First, it is necessary to outline the scientific understanding of the term human capital. The human capital is one of the components of intellectual capital [7, 8]. It came to the forefront of scientific interest in the 1960s when economists and other experts came to realize its importance.

The key role of the human capital in achieving sustainable growth, with emphasis on its society - wide impact (especially in its relation to new social constructs), has been mentioned in the work of Coleman, who claims that building trust and loyalty among members of a particular group is essential for the achievement of the society - whole objectives in any sector. This makes human capital a modern area of concern reflecting the current turbulent situation [9]. The human capital is an area sui generis, it is thus necessary to bear in mind any overlaps in the definitions of the human capital as various authors or works define it differently. For the reasons stated above, it is necessary to clearly define the term "human capital" as it is used in this paper. The general paradigm under which the human capital is understood in the present paper is in accordance with Burgess-human capital is a determinant of economic growth. The human capital is being shaped in the process of education and is among the main tools to express the level of social integration of individuals or group of individuals in each company $[10,11]$.

\subsection{Methodology}

The first impetus for this research has been raised at the Department of transport management, marketing and logistics at University of Pardubice. The survey was conducted in 2016 at a number of Czech high schools. The Czech education system is a four - tier system of preschool, primary, secondary, and tertiary education. On the secondary level, students can choose between vocational schools (which are completed by a qualification exam), professional high schools and the so - called „grammar schools“, which are both completed by a graduation exam. Students of vocational programs must take both qualification and the graduation exams if they wish to continue to study.

After leaving the high school, students of vocational and professional high schools can either start looking for a job or continue to study at higher vocational schools or universities. However, many students also like to take a kind of a "gap year" and attend an intensive language course at a language school before starting university or going to work.

In the planning stage, authors had to take into account time schedules for graduation exams at the participating high schools. Table 1 shows the survey timetable.

The survey focused on two main areas: perceived employability and motivational factors. The term "perceived employability“ as used here stands for a student's perception of his or her future employability prospects-whether they consider their knowledge and experience sufficient for their success on the job market.

The following hypotheses were proposed:

Perceived employability:

$\mathrm{H} 0^{1}$ : Interaction between respondent's first intention „(,look for a job“ or „continue to study“) and gender („male students“ or „female students“) does not affect perceived employability.

$\mathrm{H} 1^{1}$ : Interaction between respondent's first intention („look for a job“ or „continue to study“) and gender („male student" or „female student") does affect perceived employability.

$\mathrm{H}^{2}$ : No match in terms of gender has been found in evaluations of perceived employability in the group of respondents with the same first intention. 
$\mathrm{H}^{2}$ : A match in terms of gender has been found in evaluations of perceived employability in the group of respondents with the same first intention.

$\mathrm{H} 0^{3}$ : Respondent's first intention does not affect perceived employability.

$\mathrm{H} 1^{3}$ : Respondent's first intention does affect perceived employability.

Motivational factors:

$\mathrm{H} 0^{4}$ : Interaction between respondent's first intention („look for a job“ or "continue to study“) and gender („male students“ or „female students“) does not affect motivational factors.

$\mathrm{H} 1^{4}$ : Interaction between respondent's first intention („look for a job“ or „continue to study“) and gender („male students“ or „female students") does affect motivational factors.

$\mathrm{H} 0^{5}$ : No match in terms of gender has been found in evaluations of motivational factors in the group of respondents with the same first intention.

$\mathrm{H}^{5}$ : A match in terms of gender has been found in evaluations of motivational factors in the group of respondents with the same first intention.

$\mathrm{H} 0^{6}$ : Respondent's first intention does not affect motivational factors.

$\mathrm{H} 1^{6}$ : Respondent's first intention does affect motivational factors.

\subsection{Data collection methodology}

Data were obtained in a primary research initiated by authors of this study. Respondents were all students of study program no. 37-42-M/01 Logistics and financial services at high schools associated in the Association (Stredni odbornaskola logistickych sluzeb, Ucnovska 1/100, Praha; SOS informatiky a spoju a SOU Kolin, Jaselska 826, Kolin; Stredni odbornaskola a Stredni odborne uciliste, namesti Edvarda Benese 2353, Kladno; Strední odbornaskola a Stredni odborne uciliste, Volanovska 243, Trutnov; Stredni odbornaskola logisticka a stredni odborne uciliste Dalovice, Hlavni 114/29, Dalovice; Stredniskola informatiky a financnich sluzeb, Klatovska 200 G, Plzen; Stredniskola informatiky, postovnictvi a financnictvi Brno, Cichnova 982/23, Brno; Stredni prumyslovaskola, Resslova 5, Usti nad Labem; Obchodni akademie a Stredni odbornaskola logisticka, Hany Kvapilove 20, Opava; Stredniskola logistiky a chemie, U Hradiska 29, Olomouc).

They were all in their final year of study, at the end of which they sit for the school - leaving exam. That is why respondents are called „future graduates“ - in this paper, the term „graduate“ is used to mean a student who has successfully completed his or her high school studies. Respondents were thus approximately 18 years old.

The questionnaire was created in Google Forms and the survey took place from April 4 to April 22 2016. The questionnaire first divided respondents into three main groups according to what their first intention after finishing the high school was: „I want to continue to study“, „I want to look for a job“ and „I have no idea“. If a respondent chose the last option „I have no idea“, he or she was redirected to the last part of the questionnaire to respond to questions related to identification analysis:

- „Gender“

- „What high school are you studying?“

- "What is the first foreign language you study at school?"

- „Apart from the compulsory professional hands - on training, did you have any possibility to work, e.g. to have a part - time job or summer job?"

These respondents were not subjected to further investigation and their responses were not included in the sample for statistical testing, while the first two groups of respondents („I want to continue to study" and "I want to look for a job") were redirected to another part of the questionnaire, which dealt with the two main areas of the survey.

\subsection{Data processing}

A total of 157 completed questionnaires were returned, which represents $79.69 \%$ return rate. For the sake of maximum relevance, Stredni skola informatiky a financnich sluzeb, Klatovska 200 G, Plzen, had to be excluded from the survey ${ }^{1}$. Therefore, data from 102 respondents were processed. The final calculation was done on a sample of 95 respondents because 7 respondents stated they had "no idea" about their first intention. $93.13 \%$ of respondents (95 out of 102 respondents) had a clear idea about their first intention after leaving the school, which is a definitively positive finding.

Data calculation was done in two phases as there are two main areas of interest.

Perceived employability:

In this set of statements (see Appendix A), respondents had to choose one of the options: "strongly agree", "agree", "disagree", "strongly disagree". The following equation was used to express the values:

$a_{j}=\frac{1}{n} \sum_{i=1}^{n} a_{i j}$

where:

$i \quad \ldots$ is the sequence number of respondent

$j \quad \ldots$ is the sequence number of statement (see Appendix A)

$a_{j} \quad \ldots$ average score of the $\mathrm{j}$ - factor

$n \quad$... total number of respondents

${ }^{1}$ The questionnaire was submitted by high school representatives also to students of the vocational program, who cannot continue to study at university immediately after their qualification exams. Because all the obtained data were anonymous, it was not possible to separate these students' responses from the rest. As this would lead to distortion of results, the data from the whole school were excluded from the statistical testing. 


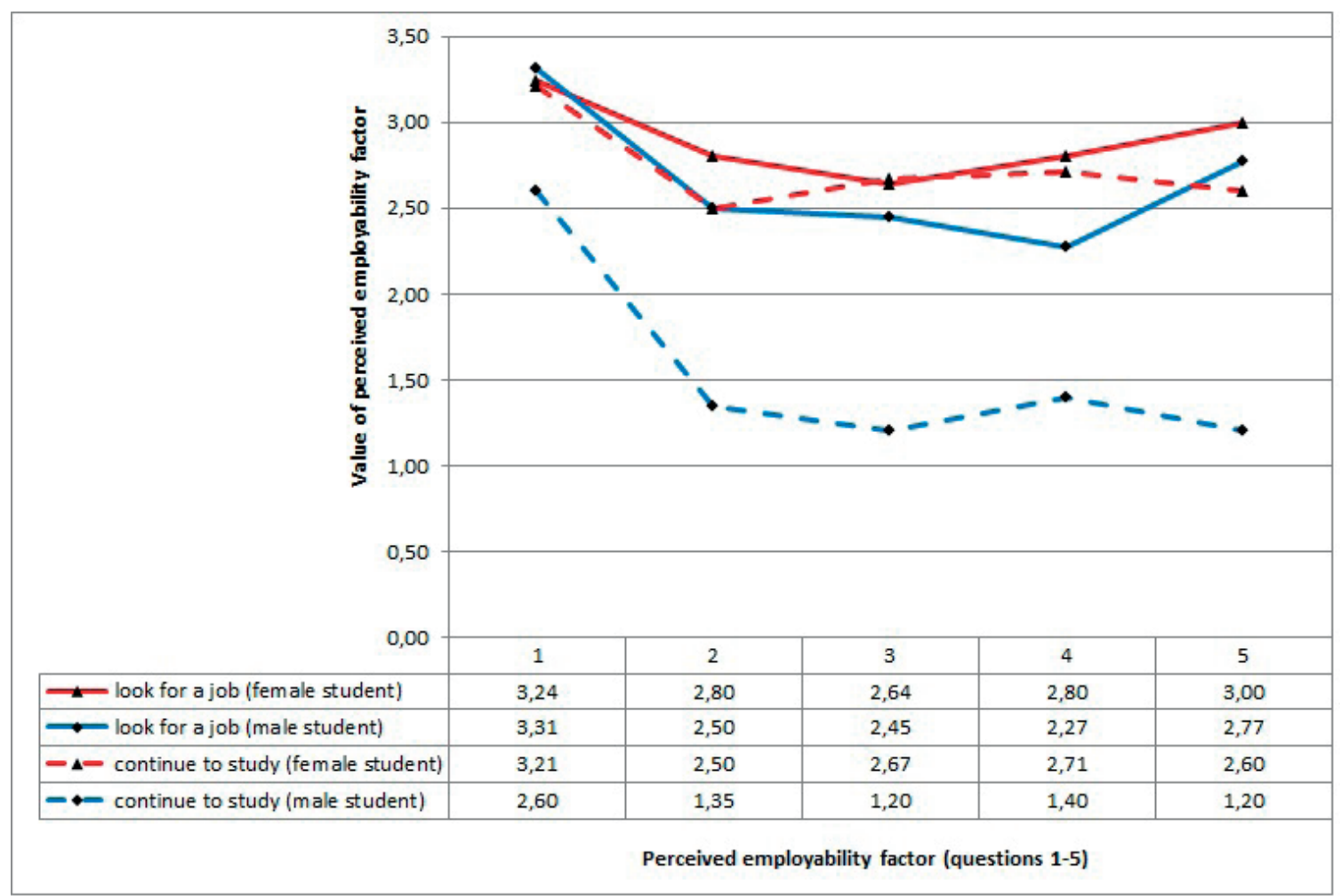

Figure 1 Value of perceived employability factor

Motivational factors:

In this set of statements (see Appendix B), respondents had to assign a grade to each factor, ranging from 1 to 6 ( 1 - rather unimportant factor, 6 - rather important factor). Respondents were free to use the grades as many times they wanted. Therefore it could have happened that respondents used the same grade for all the factors. The following equation was used to express the scores:

$$
b_{j}=\frac{1}{n} \sum_{i=1}^{n} b_{i j}
$$

\section{where:}

$i \quad \ldots$ is the sequence number of respondent

$j \quad \ldots$ is the sequence number of statement (see Appendix B)

$b_{j} \quad \ldots$ average score of the $\mathrm{j}$-factor

$n \quad$... total number of respondents

The two-way ANOVA method was used to confirm the above proposed hypotheses. This method was chosen because authors wanted to find any possible differences in values of perceived employability and motivational factors when looking at interaction of both factors, i.e. gender and the first-intention:

- first-intention („continue to study“ versus „look for a job“),

- gender (male students versus female students).

\section{Results}

\subsection{Perceived employability - results}

Figure 1 presents values calculated from respondents' answers to questions related to perceived employability (see Appendix A). Resulting values are differentiated according to:

- student's first-intention („look for a job“ or „continue to study“"),

- gender (male or female student).

Numbers 1, 2, 3, 4, 5 on the abscissa represent questions from the Perceived employability category. Results were calculated based on the methodology presented in Equation (1). Two - way ANOVA method was used to confirm hypotheses. The results are presented in Table 2.

Results show that in the area of perceived employability, hypothesis $\mathrm{H} 1^{2}$ has been confirmed, meaning that a match in terms of gender has been found in evaluations of perceived employability in the group of respondents with the same first intention.However, significant differences can be observed among responses of respondents whose first-intention is to "continue to study“. For example, the average score of question no. 1 in the „look for a job" category is 3.24 for female students and 3.21 for male students, while in the "continue to study“ category, the 


\section{kOMNlkocle}

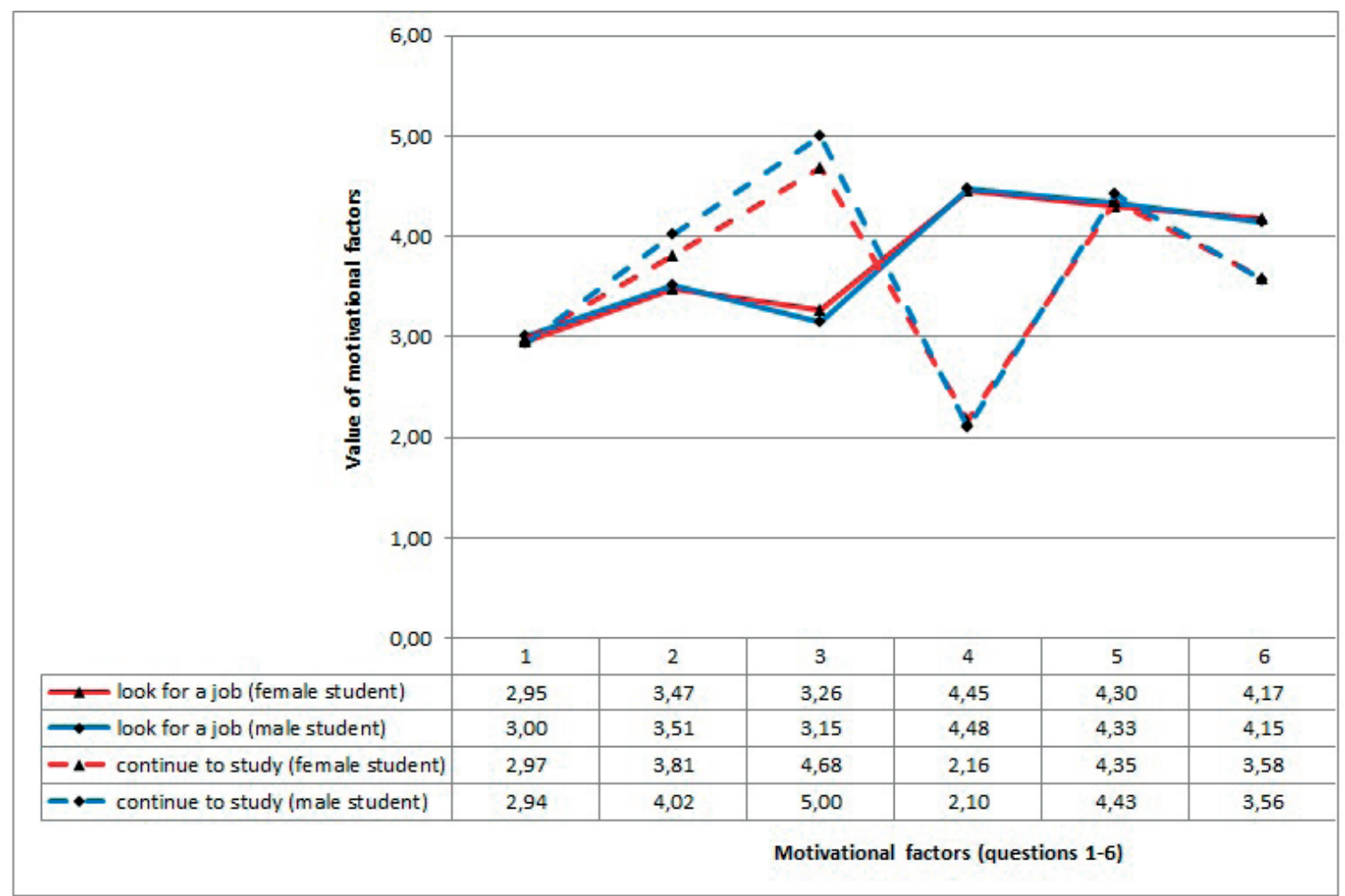

Figure 2 Value of selected motivational factors

Table 2 Analysis of results: The two - way ANOVA

\begin{tabular}{|c|c|c|c|c|c|}
\hline Source of variation & $P$ value & Sum - of - squares & Mean square & F - test & Results \\
\hline Interaction & 0.9630 & 0.2255 & 0.05637 & 0.1410 & $\mathrm{H} 0^{1}$ Accepted \\
\hline Gender & 0.0488 & 2.010 & 2.010 & 5.027 & $\mathrm{H} 1^{2}$ Accepted \\
\hline First intention & 0.3450 & 2.027 & 0.5068 & 1.268 & $\mathrm{H} 0^{3}$ Accepted \\
\hline Residual & & 3.998 & 0.3998 & & \\
\hline
\end{tabular}

Table 3 Analysis results: Two - way ANOVA

\begin{tabular}{|c|c|c|c|c|c|}
\hline Source of variation & $P$ value & Sum - of - squares & Mean square & F - test & Results \\
\hline Interaction & $\mathrm{P}<0.0001$ & 8.551 & 1.710 & 232.9 & $\mathrm{H} 1^{4}$ Accepted \\
\hline Gender & 0.0023 & 0.1094 & 0.1094 & 14.89 & $\mathrm{H} 1^{5}$ Accepted \\
\hline First intention & $\mathrm{P}<0.0001$ & 5.037 & 1.007 & 137.2 & $\mathrm{H} 1^{6}$ Accepted \\
\hline Residual & & 0.08810 & 0.007342 & & \\
\hline
\end{tabular}

difference is huge: the average score of the same question is 3.21 for female students and 2.60 for male students.

\subsection{Motivational factors - results}

Figure 2 presents values calculated from respondents' responses to questions related to selected motivational factors (see Appendix B). Resulting values are differentiated according to: 
- student's first - intention („look for a job“ or „continue to study“),

- gender (male or female student).

Numbers 1, 2, 3, 4, 5, 6 on the horizontal axis represent questions from the motivational factors category. Results were calculated on basis of the methodology presented in Equation (2). Two-way ANOVA method was used to confirm hypotheses. Results are presented in the following Table 3.

The results show that hypotheses $\mathrm{H} 1^{4}, \mathrm{H} 1^{5}$ and $\mathrm{H} 1^{6}$ have been confirmed in the area of motivational factors. Namely, it is the following hypotheses:

$\mathrm{H} 1^{4}$ : Interaction between respondent's first intention („look for a job“ or „continue to study“) and gender („male students“ or „female students") does affect motivational factors.

$\mathrm{H}^{5}$ : A match in terms of gender has been found in evaluations of motivational factors in the group of respondents with the same first intention.

$\mathrm{H} 1^{6}$ : Respondent's first intention does affect motivational factors.

\section{Conclusion}

The main objective of this study was to identify the trends of approach to human capital.The statistical testing has proved the dependence between a student's first-intention and gender, and their perceived employability and motivational factors. It has also been found that within the first-intention categories („look for a job" and „continue to study“"), a dependence of perceived employability and gender can be observed. It also shows that in the "continue to study“ category, the difference in response scores is greater than in the „look for a job“ category.

The study brings new insights into the approach to human capital in the field of communications and transport, ever more as several hypotheses have been confirmed.

There is also room for further research. One possible topic for research could be the analysis of responses in both investigated categories, i.e. perceived employability and motivational factors, from the perspective of gender (it would be possible to explain functional relationship in the motivational factors category, where there are practically no differences between male and female students).

The main advantage of this study is in the fact that it draws on current data obtained in a primary research that was conducted in 2016. The study is also rather unique as no such research on this topic has been carried out so far in the Czech Republic.

\section{Acknowledgements}

The article was supported by student the grant SGS_2017_009.

\section{References}

[1] CHANG, C. - F., WANG, P., LIU, J. - T.: Knowledge Spillovers, Human Capital and Productivity. Journal of Macroeconomics, 47, 214-232, 2016.

[2] DONATE, M. J., PENA, I., DE PABLO, J. D. S.: HRM Practices for Human and Social Capital Development: Effects on Innovation Capabilities. International Journal of Human Resource Management, 27(9), 928-953, 2016.

[3] JOH, S. W., JUNG, J. - Y.: Top Managers' Academic Credentials and Firm Value. Asia-Pacific Journal of Financial Studies, 45(2), 185-221, 2016.

[4] KUCHARCIKOVA, A., KONUSIKOVA, L., TOKARCIKOVA, E.: Approaches to the Quantification of the Human Capital Efficiency in Enterprises. Communications - Scientific Letters of the University of Zilina, 18(3), 28-33, 2016.

[5] BYRON, R. P., TAKAHASHI, H.: An Analysis of the Effect of Schooling, Experience and Sex on Earnings in the Government and Private Sectors of Urban Java. Bulletin of Indonesian Economic Studies, 25(1), 105-117, 1989.

[6] PARK, J. H.: Estimation of Sheepskin Effects Using the Old and the New Measures of Educational Attainment in the Current Population Survey. Economics Letters, 62(2), 237-240, 1999.

[7] EDVINSSON, L., MALONE, M. S.: Intellectual Capital: Realizing Your Company‘s True Value by Finding Its Hidden Brainpower. Harper Business, New York, 1997.

[8] SVEIBY, K. E.:The New Organizational Wealth: Managing and Measuring Knowledge-Based Assets, Berrett-Koehler Publishers, 1977.

[9] COLEMAN, J. S.: Social Capital in the Creation of Human-Capital. American Journal of Sociology, 94, 95-120, 1988.

[10] BURGESS, S.: Human Capital and Education: The State of the Art in the Economics of Education, Bonn, 2016.

[11] KAMPF, R., HITKA, M., LIZBETINOVA, L., CAHA, Z., XU, Y.: Facility Management-Instrument for the Management of Support Processes for HRM Outsourcing. Communications - Scientific Letters of the University of Zilina, 18(2), 37-43, 2016. 


\section{KOMNIKCCle}

\section{Appendix A: Perceived employability}

Respondents who stated they wanted to "continue to study" evaluated the following statements:

1) "Graduating from university/higher vocational school/language school will enable me to get a better position once I start looking for a job."

2) "I consider the theoretical knowledge gained at the high school sufficient for finding a job."

3) "The high school in which I study is relatively prestigious in comparison with other high schools (regarding teachers, studies organization, extracurricular activities, etc.)."

4) "I consider the practical skills gained at the high school sufficient for finding a job."

5) "I consider the language competence gained at the high school sufficient for finding a job."

Respondents who stated they wanted to "look for a job" evaluated the following statements:

1) "The acquisition and deepening of practical skills and experience (through working in my country or abroad) right after graduating from high school will enable me to get a better position once I start looking for a job."

2) "I consider the theoretical knowledge gained at the high school sufficient for finding a job."

3) "The high school in which I study is relatively prestigious in comparison with other high schools (regarding teachers, studies organization, extracurricular activities, etc.)."

4) "I consider the practical skills gained at the high school sufficient for finding a job."

5) "I consider the language competence gained at the high school sufficient for finding a job."

\section{Appendix B: Motivational factors}

Respondents who stated they wanted to "continue to study" evaluated the following statements:

1) "The university/higher vocational school/language school is within minimum distance from the place where I live (so I don't have to pay for accommodation).”

2) "My partner works/studies near the university/higher vocational school/language school."

3) "I am mainly after getting a university degree."

4) "I am attracted by the high social prestige of the university/higher vocational school/language school."

5) "Higher qualification will be an advantage in the future search for a job."

6) "It will provide me with better chances of earning a higher salary."

Respondents who stated they wanted to "look for a job" evaluated the following statements:

1) "My workplace is within minimum distance from the place where I live (so I don't have to move away)."

2) "My partner studies/works near my potential workplace."

3) "I am mainly after gaining financial independence from my parents."

4) "I am attracted by the high social prestige of the company."

5) "I like the possibility of career advancement in my future job."

6) "I like the possibility to attend further educational programs such as language courses, professional seminars, etc., paid by the employer." 